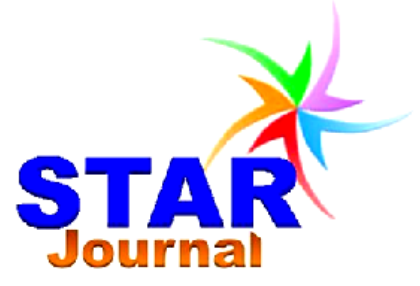

ISSN: 2226-7522(Print) and 2305-3327 (Online) Science, Technology and Arts Research Journal April-June 2012, 1(2):43-52 www.starjournal.org Copyright $\odot 2012$ STAR. All Rights Reserved

Original Research

\title{
Savanna Land Use and its Effect on Woody Plant Species Diversity in Borana, Southern Ethiopia
}

\author{
Teshome Takele Dime $^{1 *}$, Ayana Angassa ${ }^{2}$, Sileshi Nemomissa ${ }^{3}$ and \\ Tadesse Woldemariam ${ }^{4}$ \\ ${ }^{1}$ College of Agriculture \& Natural Resources, Wollega University, Post Box No: 395, Nekemte, Ethiopia \\ ${ }^{2}$ Botanical Institute, University of Cologne, Germany \\ ${ }^{3}$ College of Natural Sciences, Addis Ababa University. Addis Ababa, Ethiopia \\ ${ }^{4}$ Environment and Coffee Forest Forum, Addis Ababa, Ethiopia
}

\begin{tabular}{|c|c|}
\hline Abstract & Article Information \\
\hline A study on the diversity of woody plant species of Boke salt valley landscape & Article History: \\
\hline in a semi-arid ecosystem of Borana was conducted. The area is a volcanic & Received : 01-05-2012 \\
\hline crater lake with the lake at the bottom base. Vegetation of such volcanic areas & Revised : 10-06-2012 \\
\hline transects were laid along four geographical directions (aspects). A total of 22 & Accepted : 18-06-2012 \\
\hline $\begin{array}{l}\text { quadrats }(20 \mathrm{~m} \times 20 \mathrm{~m}) \text { were used for woody vegetation sampling and the } \\
\text { height and diameter at breast height }(\mathrm{DBH}) \text { data were collected for each }\end{array}$ & Keywords: \\
\hline species. Vegetation data were analyzed using PC-ORD, CANOCO and SPSS & Volcanic \\
\hline software. A total of 24 woody plant species representing 18 genera in 14 & Dryland Ecosystems \\
\hline families were recorded. The density of woody plants recorded in the present & Plant Community \\
\hline study was 2622 individuals $\mathrm{ha}^{-}$. The results showed that the woody plant & Saline Tolerant \\
\hline Moreover, three plant community types were identified namely: Suaeda & Halophytes \\
\hline monoica, Maerua triphylla-Acalypha fruticosa and Hibiscus aponeurus- & ${ }^{*}$ Corresponding Author: \\
\hline Solanum somalensis. However, Boke salt valley landscape is under intensive & Teshome Takele Dime \\
\hline $\begin{array}{l}\text { human exploitation. Hence, participatory natural resource management for the } \\
\text { sustainable use of such scarce resources is very crucial. }\end{array}$ & $\begin{array}{l}\text { E-mail: } \\
\text { tashomatakala@yahoo.com }\end{array}$ \\
\hline
\end{tabular}

\section{INTRODUCTION}

Ethiopia is one of the tropical countries in Africa with varied ecological and climatic conditions. The wide variation in altitude and climate probably make Ethiopia home to the most diverse flora and fauna in the world (EFAP, 1994; Woldu, 1999). Among the diversity of agro-ecological zones of the country, arid and semi-arid ecosystems represent about $620,000 \mathrm{~km}^{2}$ (Mulgeta and Demel, 2004). This huge land mass of the country is known to be dominated by dry decidious woodland and/or bushland with an estimated area of 25 million hectares.

Usually, the representative genera inhabting such dry decidious woodland and wooded grassland ecosystems of the country are
Boswellia, Commiphora, Acacia, Balanites, different types of shrubs, grasses and other plant life forms (Oba et al., 2000 and Limenih et al., 2003). However, the Borana rangelands of southern Ethiopia are characterized by the dominance of Combretum-Terminalia and Acacia-Commiphora woodlands (Dalle et al., 2005a).

Borana rangelands is one of the best remaining pastoral areas of the country with the largest herding society owing high population of cattle and other domestic animals (Coppock, 1993; Mengistu, 2003). Nevertheless, review of research work over decades has indicated that the Borana rangelands are gradually degraded experiencing both ecological and economic stresses, which could be attributed to several 
centuries of livestock grazing (Coppock, 1994; Oba et al., 2000).

According to Oromia Regional Planning and Economic Development Bureau (ORPEDB) (2000), the present study area is one of the three known potential touristic areas (Boke salt landscape, Gumigayo cultural gathering place and Boke Dilo natural well) in the Dire district with vegetations formed through the process of succession (Clarkson, 1990).

So far, various studies have been conducted in the Borana rangelands of southern Ethiopia focusing on different aspects of ecosystem function and diversity (Oba et al., 2000; Angassa and Oba, 2008a, 2010), Ethnobotany (Dalle et al., 2005b), land use changes and vegetation dynamics (Coppock, 1994; Oba, 1998; Woldu and Nemomissa, 1998; Angassa and Oba, 2008b), impacts of invasive woody plants (Coppock, 1993; Angassa, 2002) and forage scarcity (Coppock, 1994; Mengistu, 2003; Angassa and Beyene, 2003; Terefe, 2009). Despite the vast coverage and significance of previous studies, information on woody plant species diversity in the Boke salt valley landscape is lacking. Therefore, this study was undertaken with the following objectives: (1) To identify and record the diversity of woody plant species in the study area; (2) To evaluate the variation in woody plant species diversity along the four geographical aspects and; (3) To investigate the plant communities of the study area for future management and conservation measures.

\section{MATERIALS AND METHODS}

Boke salt valley landscape is found in Dire district, which is located in the southern part of Borana zone, Oromia Regional State of Ethiopia. Geographically, it is located at $4.08^{\circ} \mathrm{N}$ and $37.42^{\circ}$ E (Coppock, 1994). According to the Soda village administration office, the number of inhabitants from 2004/2005 population census was 2021 people (1122 male and 899 female) living in the village, which is located at the southern top plain of the Boke salt valley landscape.

The climate of the Borana rangeland is arid and semi-arid with a high variability of rainfall. The rainfall is bimodal in nature with the long rainy season usually occurs between March and May and the short rains from October to November (Coppock, 1994). Based on a 20 year (i.e., between 1984 and 2004) meteorological data collected from Dire meteorological station and summarized by the Ethiopian meteorological agency, the mean monthly rainfall was $47.1 \mathrm{~mm}$ with the minimum in August $(4.72 \mathrm{~mm})$ and maximum in April (148.1 mm). The mean annual rainfall in the study area was $532.2 \mathrm{~mm}$ with mean annual minimum in $1984(127 \mathrm{~mm})$ and maximum in 1997 (894 mm). There is a slight variation in mean annual temperature throughout the year, with the hottest months from January to March (maximum $26.9{ }^{\circ} \mathrm{C}$ ) and the coldest between June and August (minimum $12{ }^{\circ} \mathrm{C}$ ). The major soil types of the district are Chromic and Orthic Luvisols (45\%), Calcaric and Eutric Regosols (15\%), and Lithosols together with Humic, Mollic and Vertic Andosols (40\%) (ORPEDB, 2000).

\section{Sampling Procedures}

Reconnaissance survey was made prior to actual data collection (1) to get preliminary notes on the distribution of woody plant species; and (2) to decide the direction and number of transect lines. Then, vegetation data were collected along four transects lines (i.e., East, West, South and North) starting from the bottom base of the Boke salt valley landscape. Along each transect, vegetation data was collected in plot of $20 \mathrm{~m} \times 20$ $\mathrm{m}\left(400 \mathrm{~m}^{2}\right)$ at $100 \mathrm{~m}$ interval between sampling plots. Within each quadrat, woody plant species were counted at individual level and their diameter at breast height (DBH), and height were recorded using sunto clinometers and caliper respectively.

Voucher specimens of woody plant species were collected and pressed following the standard procedure, transported to the herbarium where it oven dried for identification and future conservation. Specimens were identified by comparing with the already identified specimens in the National Herbarium at Addis Ababa University. Plant names followed the published flora of Ethiopia books (Edwards et al., 1995; Hedberg and Edwards, 1989; Edwards et al., 2000 and Hedberg et al., 2003). Finally, specimens were deposited at the National Herbarium of Ethiopia, Department of Biology, Addis Ababa University.

Generally, the following parameters were derived from the vegetation data. The Shannon diversity Index $\left(\mathrm{H}^{\prime}\right)$, which is calculated using the formula: $\mathrm{H}^{\prime}=-\Sigma$ pi In (pi), where: $\mathrm{H}=$ Shannon Diversity Index; $\mathrm{pi}=$ the proportion of individuals or the abundance of $i^{\text {th }}$ species expressed as a proportion of the total cover in the sample and In = natural logarithms (Kent and Coker, 1992). The value of Shannon diversity index is usually found to fall between 1.5 and 3.5, while rarely surpasses 4.5 (Magurran, 1988). Then, 
Teshome Takele Dime et al.,

equitability or evenness index was calculated from the ratio of observed diversity to maximum diversity using the equation, $E=H^{\prime} / \ln (S)=$ $H^{\prime} / H_{\max }$, where: $E=$ Evenness; $H^{\prime}=$ ShannonWiener Diversity Index; Hmax = InS; S = the total number of species in the sample. The value of evenness index falls between 0 and 1 . The higher the value of evenness index, the more even the species is in their distribution within a given area (Magurran, 1988).

Species richness is a count of the total number of species in a quadrate, area or community (Oba et al., 2001). Species turnover analysis was complemented by calculating the floristic similarities between all pairs of aspects using Sorensen's similarity index (Magurran, 1988), i.e., $S s=2 C /(A+B)$, where $C=$ the number of species common to both directions, $A=$ the number of
Sci. Technol. Arts Res. J., April-June 2012, 1(2): 43-52

species present in one of the direction to be compared and $B=$ the number of species present in the other direction.

Basal area is the cross-sectional area of tree stems diameter at breast height. Generally, it is a measure of dominance where the term "dominance" refers to the degree of coverage of a species as an expression of the space it occupies, and it is usually calculated by using the following formula: $\mathrm{BA}=\Pi \mathrm{d}^{2} / 4$, where $\mathrm{BA}=$ Basal area in $\mathrm{m}^{2}$ per hectare, $d=$ diameter at breast height and $\Pi=3.14$.

The Important Value Index (IVI) of a species was calculated from the sum of relative dominance, relative density and relative frequency as recommended by Kent and Coker (1992). Each of the components of IVI was computed as described below:

$$
\begin{aligned}
& \text { Relative density }=\frac{\text { Total No. of individual species } A}{\text { Total No. of individuals of all species }} \times 100 \\
& \text { Relative frequency }=\frac{\text { Relative frequency of Species } A}{\text { Frequency of all species }} \times 100 \\
& \text { Relative dominance }=\frac{\text { Domiance of species } A}{\text { Domiance of all Species }} \times 100
\end{aligned}
$$

\section{Data Analysis}

Classification by means of hierarcical cluster analysis is the most common multivariate technique to analyze community data. A cluster analysis helps to group together a set of observations (here plots or vegetation samples) based on their attributes or floristic similarities (Kent and Coker, 1992). To this effect, a hierarchical cluster analysis was performed by using PC-ORD for windows version 4.20 (McCune and Mefford, 1999) to classify the vegetation into plant community types based on abundance data of the species in each quadrat and the Relative Euclidean Distance (RED) measures using Ward's method were used in the current study. The identified groups were tested for the hypothesis that there is no difference between groups using the multi-response permutation procedure (MRPP). Deterended Correspondence Analysis (DCA) and SPSS were also used to analyze patterns of distribution of woody plant species diversity.

\section{RESULTS AND DISCUSSION}

\section{Woody Plant Species Density and Diversity}

A total of 24 woody plant species belonging to 18 genera in 14 families were recorded in the Boke salt valley landscape (Tables 1 ). The most woody plant species rich families were belonged to Fabaceae (2 genera with 5 species), Tiliaceae (1 genus consisting of 4 species) and Euphorbiaceae and Burseraceae each having 2 genera and 3 species. However, Acacia drepanolobium- an indigenous invasive woody plant species was not recorded in the Boke salt valley landscape. The two species rich families (i.e., Fabaceae and Tiliaceae) have accounted for $38 \%$ of the total woody plant species diversity in the Boke salt valley landscape. The Shannon diversity index for the woody plant species in the study area was 2.1 , while the species evenness value was 0.661 . Moreover, Sorensen's similarity coefficient has revealed that the similarities of woody plant species diversity between aspects were not significantly different $(P>0.05)$ although there were numerical differences as it varies from 0.79 between South and East, South and North to 0.84 between South and West (Table 4). 
Table 1: Relative frequency (RF), Relative density (RD), Relative basal area (RBA), Important value index (IVI) and density per hectare (D/ha) of woody plant species in Boke salt valley landscape.

\begin{tabular}{llllll}
\hline Species & RF & RD & RBA & IVI & D/ha \\
\hline Acacia bussei & 1.9 & 0.2 & 13.5 & 15.5 & 4.5 \\
Acacia mellifera & 9.3 & 5.3 & 8.3 & 22.9 & 139.8 \\
Acacia oerfota & 0.9 & 1.1 & 0.1 & 2.2 & 28.4 \\
Acacia Senegal & 2.8 & 2.1 & 1.3 & 6.2 & 54.5 \\
Acalypha fruticosa & 8.4 & 40.0 & 0.1 & 48.5 & 1047.7 \\
Commiphora erythraea & 4.2 & 1.0 & 23.4 & 28.7 & 27.3 \\
Commiphora terebinthina & 4.7 & 1.0 & 16.0 & 21.6 & 25.0 \\
Cordia gharaf & 5.6 & 0.9 & 0.4 & 6.9 & 23.9 \\
Delonix baccal & 8.9 & 3.9 & 24.6 & 37.3 & 101.1 \\
Euphorbia abyssinica & 0.5 & 0.3 & 3.5 & 4.3 & 8.0 \\
Ozoroa insignis & 0.5 & 0.0 & 1.3 & 1.8 & 1.1 \\
Grewia bicolor & 10.3 & 15.2 & 0.6 & 26.0 & 397.7 \\
Grewia pennicillata & 3.7 & 0.5 & 0.1 & 4.3 & 13.6 \\
Grewia tembensis & 8.4 & 2.8 & 0.6 & 11.8 & 72.7 \\
Harmsia sidoides & 0.5 & 0.1 & 0.0 & 0.6 & 2.3 \\
Hibiscus aponeurus & 6.1 & 9.1 & 0.1 & 15.2 & 237.5 \\
Lannea rivae & 0.9 & 0.1 & 0.1 & 1.1 & 3.4 \\
Maerua triphylla & 3.3 & 1.0 & 0.2 & 4.4 & 25.0 \\
Salvadora persica & 6.1 & 2.0 & 4.1 & 12.2 & 53.4 \\
Sericocomopsis hildebrandtii & 2.3 & 0.9 & 0.0 & 3.3 & 23.9 \\
Solanum somalensis & 6.5 & 8.7 & 0.3 & 15.6 & 228.4 \\
Steganotaenia araliacea & 0.5 & 0.0 & 0.0 & 0.5 & 1.1 \\
Sterculia stencarpa & 0.5 & 0.0 & 0.7 & 1.2 & 1.1 \\
Suaeda monoica & 3.3 & 3.8 & 0.7 & 7.8 & 100.0 \\
\hline
\end{tabular}

The results showed that the three aspects (East, West and North) of the Boke salt valley landscape had similar number of species (18), whereas the South facing direction had only 15 woody species (Table 2). The East and West facing slopes of the Boke salt valley landscape had slightly more genera than the North and South facing aspects (Table 2). This difference in genera composition might be due to the length of time that the intensity of light received by the various geographical aspects.

A total density of 2622 woody plant stems ha ${ }^{-1}$ was recorded in the study area (Table 3 ). This value is greater than the mean density of trees and shrubs $\left(1274 \mathrm{ha}^{-1}\right)$ reported by Dalle et al. 
Teshome Takele Dime et al.,

(2005) in Dida Hara and Web sites of Borana rangeland. The highest density of woody plant species (3054 ha-1) was recorded in the west facing direction of Boke salt valley landscape followed by the southern facing direction with a total density of $2935 \mathrm{ha}^{-1}$. On the other hand, the lowest density of woody species $\left(2304 \mathrm{ha}^{-1}\right)$ was observed in the northern slope of Boke salt valley landscape. Generally, the density of woody plants
Sci. Technol. Arts Res. J., April-June 2012, 1(2): 43-52

in the adjacent outside surrounding sampling area was 1517 stems ha $^{-1}$ (Table 3). The total basal area of woody plant species in the Boke salt valley landscape was about $6.72 \mathrm{~m}^{2} \mathrm{ha}^{-1}$ (Table 4). The highest value for basal area of woody species $\left(2.357 \mathrm{~m}^{2} \mathrm{ha}^{-1}\right)$ was recorded in the western slope with the lowest in the south aspect $\left(0.7118 \mathrm{~m}^{2} \mathrm{ha}^{-1}\right)($ Table 4$)$.

Table 2: Number of woody plant families, genera and species in different aspects of Boke salt valley landscape, southern Ethiopia.

\begin{tabular}{lcccc}
\hline & East & West & North & South \\
\hline No. of families & 12 & 11 & 11 & 11 \\
No. of genera & 13 & 13 & 11 & 11 \\
No. of species & 18 & 18 & 18 & 15 \\
\hline
\end{tabular}

Table 3: Density and basal area of woody plant species in and around Boke salt valley landscape, southern Ethiopia.

\begin{tabular}{lcccc}
\hline \multicolumn{1}{c}{ Characteristics } & East & West & North & South \\
\hline Total plots & 6 & 5 & 6 & 5 \\
Total density & 733 & 520 & 553 & 587 \\
Minimum density/plot & 30 & 60 & 41 & 43 \\
Max density/plot & 160 & 163 & 169 & 173 \\
Mean density/plot & 122 & 104 & 92 & 117 \\
Density/ha & 3054 & 2600 & 2304 & 2935 \\
Basal area $\left(\mathrm{m}^{2} / \mathrm{ha}\right)$ & 2.165 & 2.357 & 0.7118 & 1.4837 \\
\hline
\end{tabular}

Table 4: Sorensen's similarity coefficient in woody plant species diversity between the four aspects in Boke salt valley landscape, southern Ethiopia.

\begin{tabular}{ccccc}
\hline $\begin{array}{c}\text { Geographic } \\
\text { Direction }\end{array}$ & East & West & North & South \\
\hline East & & & \\
West & 0.83 & & & \\
North & 0.83 & 0.83 & & \\
South & 0.79 & 0.84 & 0.79 \\
\hline
\end{tabular}

\section{Importance Value Index}

The Importance Value Index (IVI) for the woody plant species in Boke salt valley landscape was given in Table 1. The result showed that Acalypha fruticosa (IVI = 48.5), Delonix baccal $(\mathrm{IVI}=37.3)$, Commiphora erythraea (IVI = 28.7) 
and Grewia bicolor (IVI = 26) were among the woody plant species of the study area with the highest IVI. Furthermore, Delonix baccal, Commiphora erythraea, and Commiphora terebinthina have the highest relative basal area (Table 1). On the other hand, Acalypha fruticosa and Grewia bicolor were found to have the highest relative density and Grewia bicolor, Acacia mellifera and Delonix baccal have the highest relative frequency in Boke salt valley landscape. The current findings are in agreement with previous studies (Dalle et al., 2005a; Terefe, 2009) suggesting that certain woody species had the highest relative frequencies in Borana rangelands. Similarly, others (Angassa and Oba, 2008a) have reported that Commiphora africana and Lannea rivae were the most frequent woody plant species recorded in the region of southern rangelands of Ethiopia, especially in Dida Hara and Web areas.

\section{Population Structure of Woody Plants}

It has been asserted that diameter class distribution of the woody plant species could indicate the general trends of a population dynamics and recruitment process of a given species (Senbeta, 2006). According to White (1983), the vegetation types of Africa were classified into 20 phytochoria indicating that four were found in Ethiopia (Sudanian regional center of endemism, Somalia-Massai Regional Center of Endemism, Afromontane Regional Center of Endemism and Afroalpine Regional Center of Endemism). The vegetation of the present study was within in the classification of Somalia-Massai Regional Center of Endemism, which is characterized by having a flora dominated by Acacia (usually called Acacia-Commiphora) woodland. According to Kelbessa et al. (1992), Acacia-Commiphora woodland is found mainly between altitudes of $500 \mathrm{~m}$ and 1900 m.a.s.l, with average annual temperatures of $18{ }^{\circ} \mathrm{C}$ to $27^{\circ} \mathrm{C}$ and annual rainfall between $410 \mathrm{~mm}$ and 820 $\mathrm{mm}$, which directly fits with the environmental characteristic of the Borana rangeland. However, in the current study the absence of mature individuals of Suaeda monoica could be due to its extensive uses for the extraction of table salt from the Crater Lake. With regard to the remaining species such as Salvadora persica, Delonix baccal, Commiphora erythraea and Commiphora terebinthina, the uneven population structure may be attributed to the absence of mature individuals where selective logging may account for the observed results (Figure 1). Overall, extensive human exploitations of woody plant species with a high value of $\mathrm{DBH}$ in the adjacent outside surrounding area might be attributed to the least basal area of woody plant species as compared to all aspects of the Boke salt valley landscape, which could be utilized in terms of firewood, house construction and fencing materials. If the current exploitation of Suaeda monoica continues unchecked, the population biology of this species would critically be endangered sooner or later.

\section{Plant Communities Type}

We identified three types of plant communities following a hierarchical cluster analysis (Fig 2). The number of different community groups were decided based on MRPP technique which allows no differences in hypothesis $(\boldsymbol{T}=-9.829, \mathrm{P}<$ 0.001 and the agreement statistic, $\mathbf{A}=0.378$ ). Generally, the test statistic- $T$, describes the separation of groups and the more negative $T$ value shows the stronger the separation into the different community groups. On the other hand, the agreement statistic, $\mathbf{A}$, describes the within group homogeneity compared to the random expectation and falls between 0 and 1 . If the within groups are identical, $A=1$ and if the within groups are heterogeneous, $A=0$. In the current study, the three cluster solutions of the woody plant communities were considered optimal and the null hypothesis was rejected. This explains that the three community groups have occupied different regions of species space as revealed by the strong chance correction within the group $(A)$ and test statistic $(\boldsymbol{T})$. The plants communities are described below.

Suaeda Monoica Community: This community is dominated by Suaeda monoica. The common woody plant species of this community were Cordia gharaf, Acacia oerfota, Grewia tembensis and Lannea rivae. This community is saline tolerant and the woody plant species could be considered as halophytes since they occupy areas very close to the salt Lake at the base of the Boke valley landscape. It is also to be noted that the woody plant species of Suaeda monoica community become rare as one goes farther from the salt Lake base up the hill strengthening the assertion that they are halophytes. Worth mentioning is a complete absence of suaeda monoica after an altitude of 1140 m.a.s.l. away from the Lake in the Boke salt valley landscape. 
Comm iphora erythraea

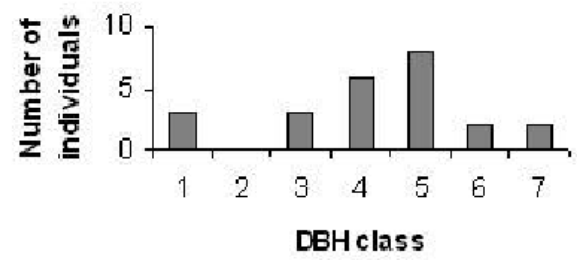

Salvadora persica

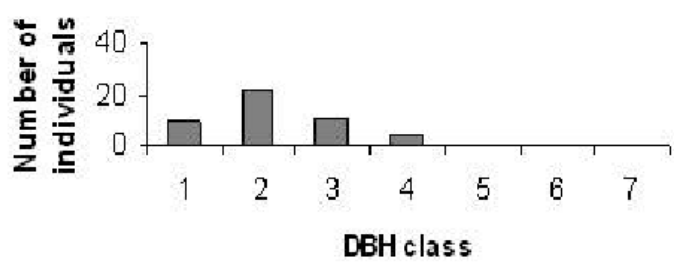

Acacia mellifera

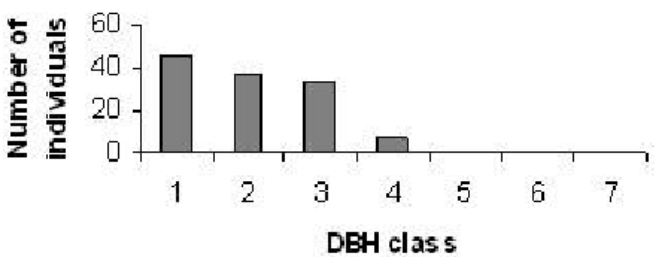

Suaeda monoica

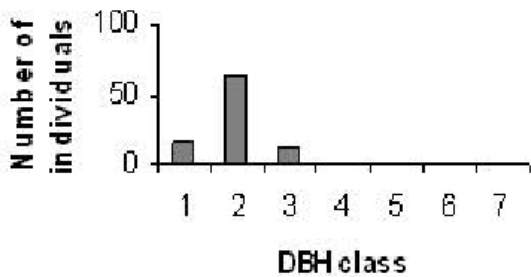

Delonix baccal

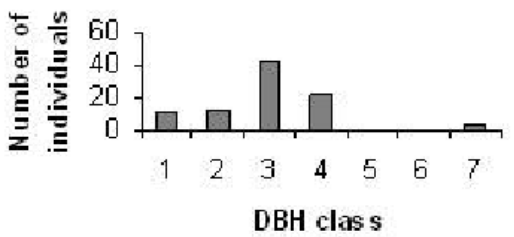

Comm iphora tetebinthina

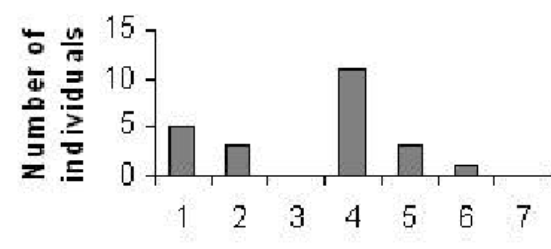

DBH class

Figure 1: Diameter class frequency distribution of selected woody plant species in Boke salt valley landscape, southern Ethiopia.

\begin{abstract}
Maerua triphylla -Acalypha fruticosa Community: This community is dominated by Maerua triphylla. The common woody plant species of this community are Grewia bicolor and Acacia Senegal. This community is located at an altitude ranging between 1161 and 1219 m.a.s.l. (mid altitude in the case of Boke salt valley landscape) just next to community 1 uphill away from the Lake.
\end{abstract}

Hibiscus aponeurus-Solanum somalensis community: This community is the most woody plant species rich (23 species) as compared to the other two communities. Except suaeda monoica all species recorded in the study area were found in this community. This community occupied a specific habitat of the Boke salt landscape ranging from1170 - 1246 m.a.s.l. at higher altitude of the valley.

For example, Woldu and Nemomissa (1998) have identified seven plant communities in the central plateau of Borana that included: Tarconanthus camphorates woodland,
Commiphora woodland, Acacia drepanolobiumAcacia seyal woodland, Chrysopogon plumulosus grassland, Barbeya oleoides-Combretum molle woodland, Clausena anisata-Panicum arundinacea and Juniperus procera-Clausena anisata forest. On the other hand, Dalle et al., (2005) have reported eight plant communities in the lowlands of Borana such as Acacia drepanolobium-Pennisetum meziamum, Bidens hildebrandtii- Chrysopogon aucheri, Chrysopogon aucheri-Commiphora africana, Cenchrus ciliarisChrysopogon aucheri, Acacia busseiPennisetum meziamum, Commiphora erythraeaSansevieria ehrenbergi, Acacia mellifera-Setaria verticillata and Heteropogon contortusHildebrandtia obcordata.

Of the seven plant communities identified by Woldu and Nemomissa (1998) in the central plateau of Borana, four of them were not found in the report by Dalle et al. (2005). Although the seven community types of the central plateau and eight of the lowland Districts of Borana were identified by different scholars, none of these 


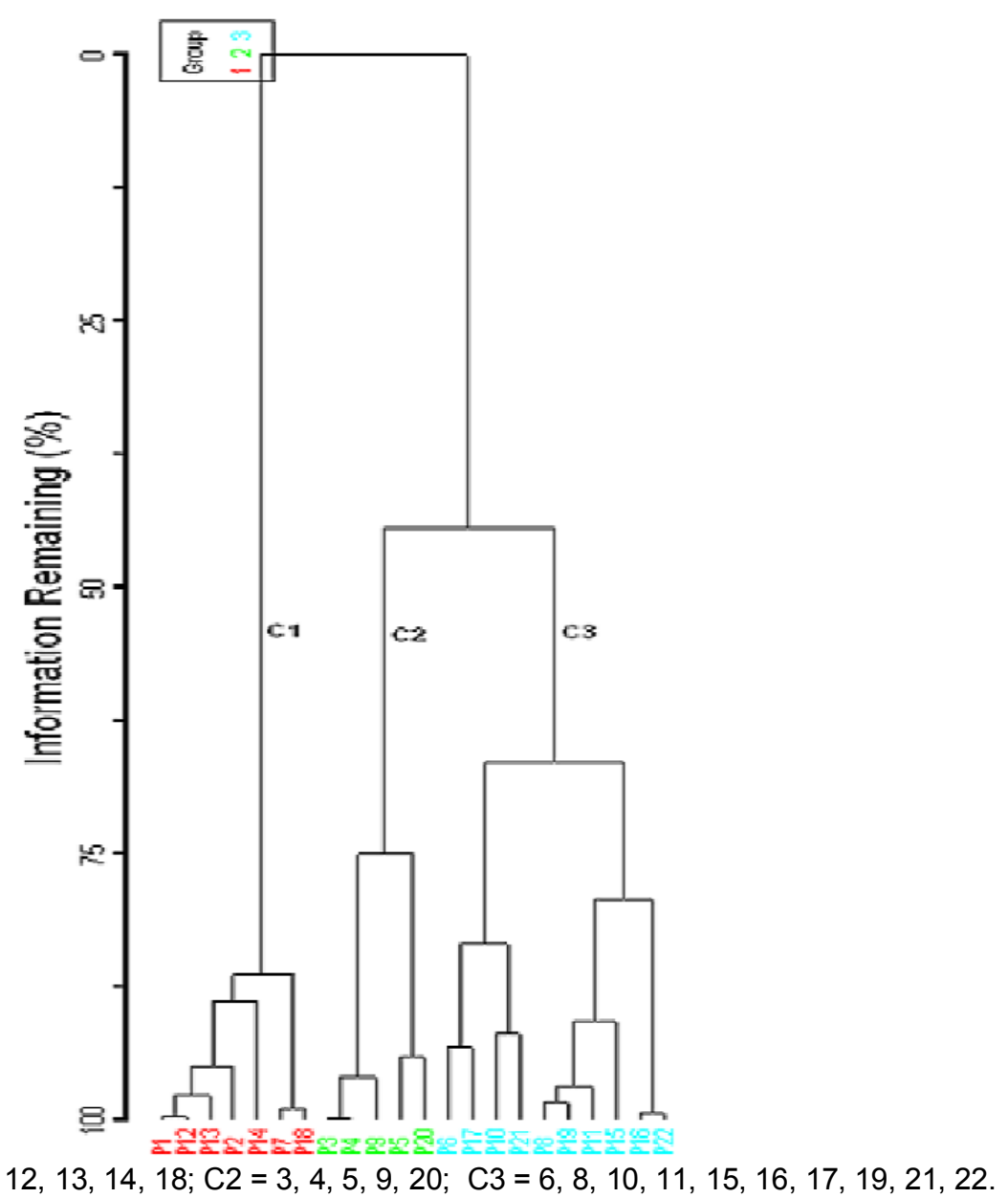

Figure 2: Dendrogram of the cluster analysis result of 24 woody plant species abundance found in 22 plots in Boke salt valley landscape, southern Ethiopia.

were recovered in the Boke salt valley landscape in the present study. This may suggest that the Boke salt valley landscape could be an isolated system of its own because of the complex interactions of local climate and environmental conditions. Generally, it could be considered as an 'open hot-air hole' packed with unique plant communities in the dry lands of Borana. Analytical presentation of the abundance of plant community types in the Boke salt valley landscape may give a clue to the degree of anthropogenic impacts apart from the impact of environmental factors. As one can deduce from the Shannon diversity index (Table 5), it was found out that plant community 1 is limited in abundance owing to unchecked human exploitation. On the other hand, plant community 2 is relatively more abundant than the other two community groups because of the observed less diversity of woody plant species of outstanding economical importance at a local scale although some of them such as Acacia senegal (gum
Arabic) displays a global economic reputation elsewhere. It is to be noted that although plant community 3 has the highest woody plant species diversity, it is not that ubiquitous in the Boke salt valley landscape owing to its proximity to anthropogenic impacts. Selective logging which has been exacerbated due to relaxed cultural exercises may account for its dwindling trend.

\section{CONCLUSIONS}

In the current study, 24 woody plant species belonging to 14 different families were recorded, which were taxonomically identified. The result showed that the Shannon diversity and evenness indices were 2.1 and 0.661 , respectively. Cluster analysis of the woody plant species data displayed three community types, which were distinct in terms of species composition. The present finding identified a completely different community types from those community types reported by earlier authors (e.g., Woldu and Nemomissa, 1998; Dalle et al., 2005) in the 
Teshome Takele Dime et al.,

drylands of Borana, southern Ethiopia. Overall, the mean diversity index for the three plant community types was 1.92 , which varies from an index value of 1.60 for community type 2 to 2.25 for community type 3 when considering the 24 woody species in the Boke salt valley landscape. The mean evenness index for the three plant community types was 0.664 with the highest value for community 3 (0.789) and lowest for community $2(0.504)$. Species richness was the highest for community type 3 (23 species) and least for community type 2 (15 species). Moreover, Acacia drepanolobium, which is notorious invasive woody plant species, causing acute problem around the study area is not observed in the salt house. Despite the Boke salt valley landscape is a key resource area for rangeland production and livelihoods for pastoral households, it is currently under severe pressure. We suggest the incorporation of indigenous knowledge in scientific research for sustainable development and management of scarce key resources in pastoral areas. Community awareness through proper extension and communication seems crucial for the resilience of rangeland key resources.

\section{ACKNOWLEDGEMENTS}

We thank SIDA/SAREC for the financial support, Ashenafi Degefe for assisting during data collection and the Department of Biology, Addis Ababa University for identification of specimens. We also thank the Dire district administration office and Bureau of Agriculture and Soda Village community for their kind cooperation during data collection.

\section{REFERENCES}

Angassa, A. (2002). The effects of clearning bushes and shrubs on range condition in Borana, Ethiopia. Tropical Grasslands 36: 69-76.

Angassa, A., Beyene, F. (2003). Current range condition in southern Ethiopia in relation to traditional management strategies: The perception of Borana pastoralists. Tropical Grasslands 37: 53-59.

Angassa, A. and Oba, G. (2008a). Effects of management and time on mechanisms of bush encroachment in southern Ethiopia. African Journal of Ecology 46: 186-196.

Angassa, A. and Oba, G. (2008b.) Herder perceptions on impacts of range enclosures, crop farming, fire ban and bush encroachment on the rangelands of Borana, southern Ethiopia. Human Ecology 36:201215.

Angassa, A. and Oba, G. (2010). Effects of grazing pressure, age of enclosures and seasonality on bush cover dynamics and vegetation composition in
Sci. Technol. Arts Res. J., April-June 2012, 1(2): 43-52

southern Ethiopia. Journal of Arid Environments 74: $111-120$.

Clarkson, B. D. (1990). A review of vegetation development following recent (450 years) volcanic disturbance in North Island, New Zealand. New Zealand Journal of Ecology 14: 59 - 71.

Coppock, D. L. (1993). The Borana Plateau of Southern Ethiopia: Synthesis of Pastoral Research, Development and Change, 1980-1991. ILCA System Study, Addis Ababa, Ethiopia.

Coppock, D. L. (1994). The Borana plateau of Southern Ethiopia: Synthesis of pastoral research, development and changes 1980-90. International Livestock Center for Africa, Addis Ababa, Ethiopia.

Dalle, G., Brigitte, L. M. and Johannes, I. (2005a). Plant community and their species diversity in the semi-arid rangelands of Borana lowlands, southern Oromia, Ethiopia. Community Ecology 6: 167-176.

Dalle, G., Brigitte, L. M. and Johannes, I. (2005b). Plant Biodiversity and Ethnobotany of Borana Pastoralists in Southern Oromia, Ethiopia. Journal of Economic Botany 59: 43-65

Edwards, S., Mesfin, T. and Hedberg, I. (Eds.) (1995). Flora of Ethiopia and Eritrea. Vol. 2, part 2. Addis Ababa University, Ethiopia and Uppsala University, Sweden.

Edwards, S., Mesfin, T., Demissew, S. and Hedberg, I. (Eds.) (2000). Flora of Ethiopia and Eritrea. Vol. 2, part 1. Addis Ababa University, Ethiopia and Uppsala University, Sweden.

EFAP. (1994). Ethiopian Forestry Action Program Vol. II-The challenges for development. Transitional Government of Ethiopia, Ministry of Natural Resources Development and Environmental Protection, Addis Abeba.

Hedberg, I., Edwards S. (Eds.) (1989). Flora of Ethiopia and Eritrea. Vol. 3. Addis Ababa and Asmara, Ethiopia and Uppsala, Sweden.

Hedberg, I., Edwards, S. and Nemomissa, S. (Eds.) 2003. Flora of Ethiopia and Eritrea. Vol. 4, part 1. Addis Ababa, Ethiopia and Uppsala, Sweden.

Kelbessa, E., Demissew, S., Woldu, Z., Edwards, S. (1992). Some Threatened Endemic Plants of Ethiopia. In: Edwards, S. and Zemede Asfaw (Eds.). Botany 2000: East and Central Africa. Napreca Monograph Series no. 2. Napreca, Addis ababa, pp. 35-45.

Kent, M. and Coker, P. (1992). Vegetation descrption and analysis: A practical approach. Belhaven press, London. Pp.363.

Limenh, M., Tarekegn, A. and Olsson, M. (2003). Gum and Resin Resources from some Acacia, Boswellia and Commiphora Species and their Economic Contribution in Liben, Southeast Ethiopia. Journal of Arid Environment 55: 465 - 482.

Magurran, A. E. (1988). Ecological diversity and its measurement. Chapman and Hall, London. 
Teshome Takele Dime et al.,

Mccune, B. and Mefford, M. J. (1999). Multivariate analysis of ecological data version 4.20, MjM software, Gleneden Beach, Oregon, USA.

Mengistu, A. (2003). Effects of Drought on the Resource Base of Borena Pastoral System in Ethiopia. In: Sustainable Biodiversity Management for Reduced Community Vulnerability to Drought. Proceeding of the $4^{\text {th }}$ RPSUD Workshop (Oyieke et al., eds). Nairobi, Kenya. Pp.143-152.

Mulugeta, L. and Demel T. (2004). Natural gum and resin resources: Opportunity to integrate production with conservation of biodiversity, control of desertification and adapt to climate change in the drylands of Ethiopia. Paper Presented to the First National Workshop on Conservation of Genetic Resources of Non Timber Forest Products (NTFPs) in Ethiopia, 5 - 6 April 2004. Addis Ababa.

Oba, G. (1998). Assessment of Indigenous Range Management of the Booran Pastoralists of Southern Ethiopia. GTZ: Borana Lowland Pastoral Development Programme.

Oba, G., Post, E., Syvertsen, P. O. and Stenseth, N. C. (2000). Bush cover and range condition assessments in relation to landscape and grazing in Southern Ethiopia. Landscape Ecology 15: 535 546.

Oba, G., Vetaas, Ole R. and Stenseth, Nils C. (2001). Relationships between biomass and plant species richness in arid-zone grazing lands. Journal of Applied Ecology 38: 836 - 845.
Sci. Technol. Arts Res. J., April-June 2012, 1(2): 43-52

Oromia Bureuobureau of Planning and Economic Development. (2000). Physical and Socio-economic Profiles of 180 Districts of Oromia. Physical Planning Department, Finfinne.

Senbeta, F. (2006). Biodiversity and ecology of Afromontane rainforests with Wild Coffee arabica L. populations in Ethiopia. Doctoral dissertation, Ecology and Development series No. 38, University of Bonn, Germany.

Terefe, B. (2009). Impact of Acacia drepanolobium: an indigenous invasive woody species on gum-resin resources and local livelihood in Borana, southern Ethiopia. MSc Thesis. Hawassa University, WondoGenet College of Agriculture. WondoGenet.

White, F. (1983). The vegetation of Africa. UNESCO, Paris.

Woldu, Z. and Nemomissa, S. (1998). Vegetation change in the central Borana plateau region of southern Ethiopia. Coenoses 13: 137-148.

Woldu, Z. (1999). Forests in the vegetation types of Ethiopia and their status in the geographic context. In: Edawards, S., Abebe Demissie, Taye Bekele and G. Haase (Eds.). Forest genetic resources conservation: Principles, strategies and actions. Proceeding of the national forest genetic resource conservation strategy development workshop. June 21-22, 1999. Addis Ababa, Ethiopa. Institute of Biodiversity Conservation and Research (IBCR) and Germen Technical Cooperation (GTZ). pp.1-38. 